\title{
LIVING ON CROATIAN ISLANDS - PERCEPTIONS AND REALITIES OF ISLAND DEVELOPMENT POLICY
}

\author{
Željka Kordej-De Villa ${ }^{1}$ \\ Sunčana Slijepčević ${ }^{2}$
}

DOI: https://doi.org/10.31410/ITEMA.S.P.2020.47

\begin{abstract}
The Croatian islands make the second-largest archipelago in the Mediterranean. There are 1244 islands (78 islands, 524 islets, and 642 rocks and rocks awash) that are situated in a range of $450 \mathrm{~km}$ along the eastern coast of the Adriatic Sea. The total area covers 3300 $\mathrm{km} 2$ (about $5.8 \%$ of Croatian mainland territory) and the length of their coast is $4057 \mathrm{~km}$. Twenty of these islands occupy an area larger than $20 \mathrm{~km} 2$ each, and the other 58 ones have a surface from $1 \mathrm{~km} 2$ to $20 \mathrm{~km} 2$. There are 47 islands that are permanently inhabited. Administratively, islands belong to seven coastal counties and 51 island towns/municipalities. Several small islands are in the jurisdiction of seven coastal cities.

By the Constitution, islands are considered as a region of special protection and unique value. Islands specificities require development policy that takes account of demographic, economic, environmental, and other island issues. In the situation of the COVID-19 pandemic, island development policy becomes even more challenging and complex.

This paper aims to analyse the attitudes and perceptions of the islanders about the living conditions on the island and the impact of public policies on island development. Identifying the problems from the local perspective helps us to evaluate the success of island development policy. Effective island policy increases the quality of life of the islanders while respecting island specifics. For this purpose, the results of a survey conducted on a sample of the inhabitants of Croatian islands conducted in 2020 are used. The surveys were conducted using the online tool LimeSurvey. The results indicate that 42 percent of the islanders think that living conditions on the islands are not improving. Most of the islanders think that government policy does not encourage island development. The paper also identifies factors that are responsible for differences in attitudes and perceptions of islanders.
\end{abstract}

Keywords: Islands, Living conditions, Development policy.

\section{INTRODUCTION}

7 he Croatian islands make the second-largest archipelago in the Mediterranean. There are 1244 islands (78 islands, 524 islets, and 642 rocks and rocks awash) that are situated in a range of $450 \mathrm{~km}$ along the eastern coast of the Adriatic Sea. The total area covers $3300 \mathrm{~km}^{2}$ (about $5.8 \%$ of Croatian mainland territory) and the length of their coast is $4057 \mathrm{~km}$. Twenty of these islands occupy an area larger than $20 \mathrm{~km}^{2}$ each, and the other 58 ones have a surface from $1 \mathrm{~km}^{2}$ to $20 \mathrm{~km}^{2}$. There are 47 islands that are permanently inhabited. According to the last population census (2011), there were only 124,842 islanders, representing $2.8 \%$ of the total population. Administratively, islands belong to seven coastal counties and 51 island towns/municipalities. Several small islands are in the jurisdiction of seven coastal cities.

The Institute of Economics, Zagreb, Trg J.F. Kennedyja 7, 10000 Zagreb, Croatia

The Institute of Economics, Zagreb, Trg J.F. Kennedyja 7, 10000 Zagreb, Croatia

Based on data of Hydrographic Institute of the Republic of Croatia 
This paper aims to analyse the attitudes and perceptions of the islanders about the living conditions on the island and the impact of public policies on island development. Identifying the problems from the local perspective helps us to evaluate the success of island development policy. Effective island policy increases the quality of life of the islanders while respecting island specifics. For this purpose, the results of a survey conducted on a sample of the inhabitants of Croatian islands conducted in 2016 and 2020 are used. The surveys were conducted using the online tool LimeSurvey. The results indicate that island policy has not changed significantly in the recent 20 years.

The paper consists of four parts. After the introduction, we proceed with elaborating the features of the island development policy. In the third chapter, we describe the methodology, used data, and present results. The paper ends with a conclusion and recommendation for future research.

\section{SPECIFICS OF ISLAND DEVELOPMENT POLICY}

By the Constitution ${ }^{4}$, islands are considered as a region of special protection and unique value. Islands specificities require development policy that takes account of demographic, economic, environmental, and other island issues.

The island development policy has a long tradition ${ }^{5}$, but policy decisions on island development have always been made on the mainland. Croatia is one of the few countries in the world which has introduced an island development strategy and adopted the special Islands Act. Although Croatia has rather long experience in governing island development, key development issues are remaining unanswered.

Although before 1997 development policy neglect island development specificities, Croatia has never ignored island connections to the mainland. The National Island Development Program (NIDP) was adopted in February $1997^{6}$ and the first Islands Act was adopted in 1999 (OG 34/1999)'.

The Islands Act defined the formulation of 26 Sustainable Island Development Programs (SIDP) and the preparation and implementation of 14 State Programs for Island Development (SPID), which deal with specific sectors and social activities on all the islands. The state programs refer to traffic connections between islands and the mainland and between the islands themselves, the water supply and treatment of wastewater, electricity supply, island telecommunications, health care and telemedicine, preschool, primary and secondary education, and the organization of the cadastre and land registry. The Act also stipulated the Annual Island Program which includes all projects from the Sustainable Island Development Program and the state programs to be financed from the State Budget. Therefore, there was a tool for governing island development policy with both bottom-up (SIDP) and top-down (SPID) components. There are three profound amendments to the 1999 Islands Act (OG 149/1999, 22/2002 and 33/2006), and the new Islands Act was adopted in 2018 (OG 116/2018).

4 The Constitution of the Republic of Croatia, known as the Christmas Constitution, was adopted on 22 December 1990. Article 52 states: "The sea, seashore, islands, ... and other natural resources, .... which are specified by law to be of interest to the Republic of Croatia shall enjoy its special protection. The manner in which any resources of interest to the Republic of Croatia may be used and exploited .... shall be regulated by law." (Kordej-De Villa and Starc, 2020: 230). Starc et al. (1997). 
The new Act is better balanced than the old one. For the first time in a legal act, the notion of islandness ${ }^{7}$ appears (Kordej-De Villa and Starc, 2020: 243).

From the reports on the implementation of the Island Act, it can be concluded that Croatia has been investing significant funds in island development. The reports present all public expenditures within the year, as well as various EU funds and development loans given by the Croatian Bank for Reconstruction and Development and the Council of Europe Development Bank. Between 2016 and 2019, non-returnable funds invested from the State Budget and EU funds in island development (75\%) and average credit investment in island development $(25 \%)$ totalled 1135 million EUR.

Figure 1. Total investment in island development in the period 2016-2019

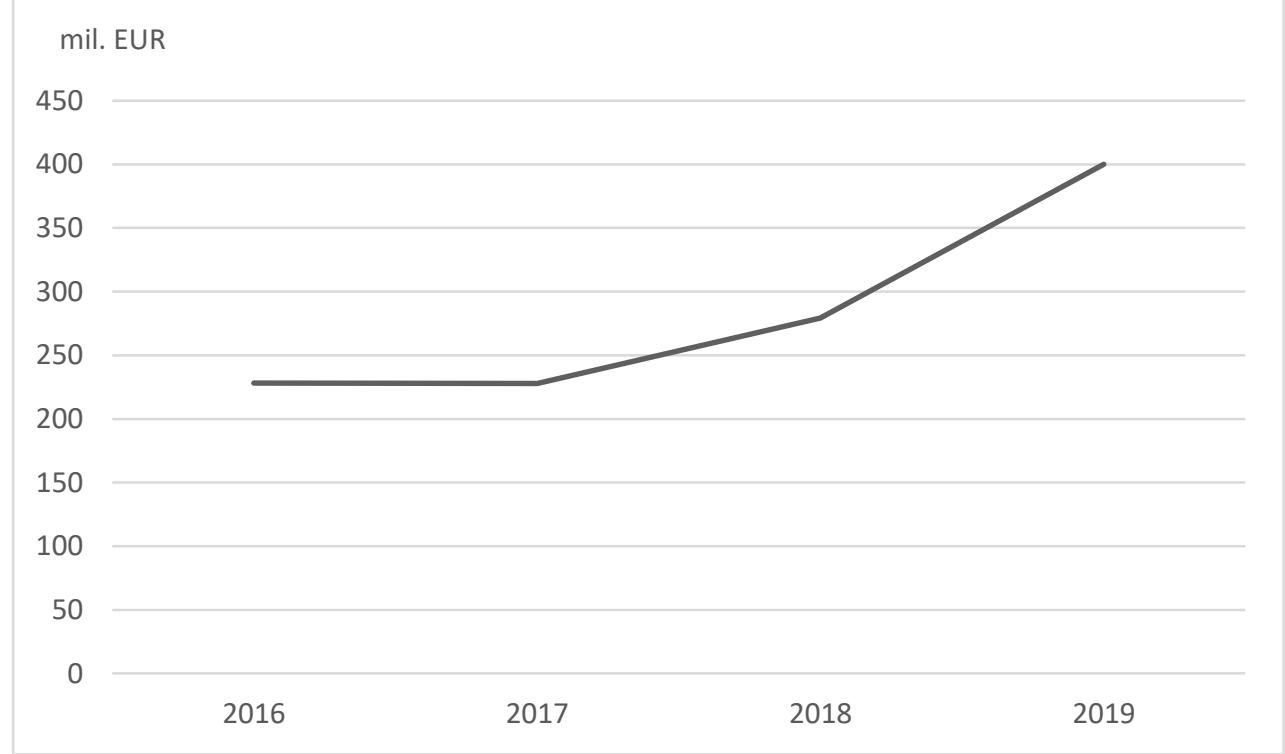

Source: Report on impacts of the implementation of the Island Act, different years

At the beginning of the 1990s European island policy began to emerge ${ }^{8}$. Its most important document, the Resolution on the Special Situation of Islands, was adopted by the EU Parliament in 2015. In 2016, the Smart Islands Initiative formulated the Smart Islands Declaration. These campaigns and policy documents bring the topic of islands to the forefront of European development policies.

\section{METHODOLOGY, DATA AND RESULTS}

In 2016, Starc (2017) surveyed the advantages and disadvantages of island life and island policy. 602 responses were collected from people which are living and/or working on the island. The results indicate that about a third of respondents ( 29.2 percent) believe that island conditions have been deteriorating in the last 15 years. Respondents consider limited employment opportunities to be the biggest problem of life on the island. As many as twothirds (66 percent) of respondents consider that limited employment opportunities are one of

Islandness is defined as "a set of geographic, social, historical, economic and ecological specificities resulting from being completely surrounded by the sea." (Article 5).

8 The first network of island authorities (ISLENET) was founded in 1993. In 2007, The EU Parliament adopted the Motion for Resolution which recommended customized measures for European islands. In 2011, a political initiative for European islands, called the Pact of Islands, was recognized by the European Parliament. 
the five most significant problems on the Croatian islands. This is followed by an increasingly elderly population (46 percent of respondents), rare connections with the mainland (44 percent of respondents), a lack of doctor specialists (40 percent of respondents), and limited opportunities for progression in the professional career (34 percent of respondents). The problems of accessibility of island settlements concerning the mainland, which is especially visible on islands that are connected to the mainland only indirectly through another, neighbouring island are also noticed by other researchers (e.g. Marinković, 2018). The analysis of the public services on the islands conducted by Marinković (2018a) showed that only 19 percent of the settlements on the islands have a doctor, and only 12 percent have one of the specialized medical doctors which clearly shows the problem with the accessibility of health services on islands ${ }^{9}$.

On the other hand, the beauty of nature and the environment, and a peaceful and healthy lifestyle are considered the main advantages of living on the islands, and such an attitude is especially prevalent among respondents who continuously live on islands (Starc, 2017). As expected, the attitude that limited employment opportunities and limited opportunities for progression in the professional career are among the biggest problems of the island's everyday life is more prevalent among the younger population. Interestingly, the aging of the population is the biggest problem for respondents of older age groups (67.4 percent of respondents aged 61 and over) and the least for respondents aged 31 to 40 (42.4 percent of respondents of that age group). It is surprising that "rare connections with the mainland" are a bigger problem for people who do not live on the islands or occasionally live on the island than for people who have lived on the island since birth. This problem is considered significant by 57.4 percent of respondents who do not live on the island and 56.2 percent of those who live on the island occasionally. Respondents believe that the state implements an island policy that mostly neglects small islands, especially those that are further away from the mainland ${ }^{10}$.

Figure 2. Basic problems of everyday life on the island, $n=602,2016$

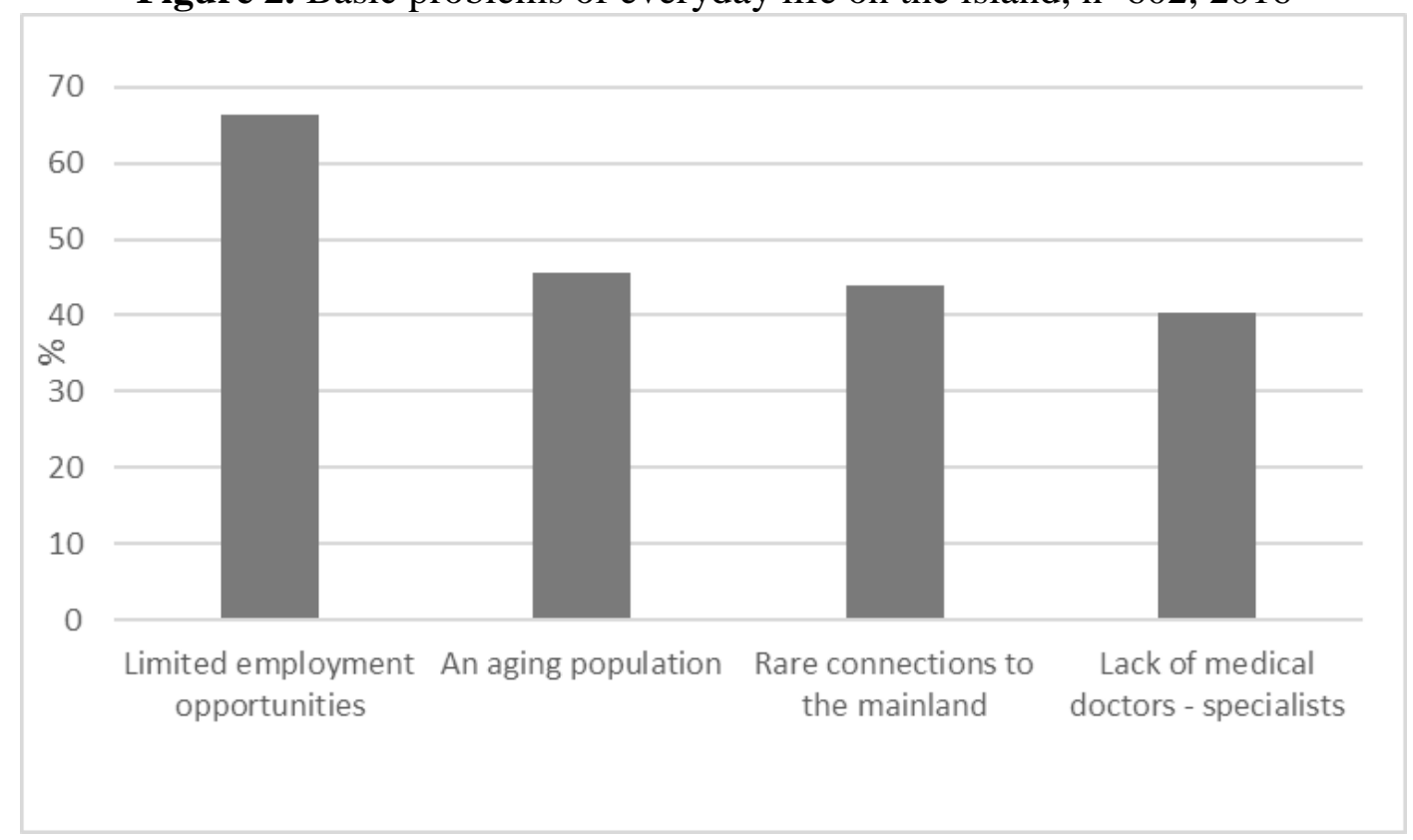

Source: Starc, 2017 
After elaborating on the main problems on the islands, we wanted to investigate whether islanders think that the situation on the islands has been improving and what factors affect a certain perception of the population about everyday life on the islands. The analysis is based on the results of the survey conducted among people who permanently or occasionally live on the islands. The survey was conducted in June of 2020. The survey collected views on the living conditions on the island and the impact of public policies on island development. The questionnaire was collected from 205 respondents. Data collection was performed using the LimeSurvey tool for the development of survey questionnaires, which is intended for the collection of anonymous responses from respondents. The statistical program SPSS Statistics 23 was used for data analysis.

The basic claims analysed in the paper are "Island living conditions are improving" and "State island policy encourages the development of all islands". Respondents had to rate these statements on a scale from 1 (strongly disagree) to 5 (strongly agree). Also, data were collected about the island on which the respondent permanently or occasionally are living. Since this was not a mandatory question, the data on the islands covered by the survey is not fully known because about half of the respondents did not answer this question. Also, some respondents have a residence on two islands. Islands included in the analysis are Cres, Dugi otok, Ilovik, Iž, Krk, Lošinj, Olib, Pag, Pašman, Rab, Silba, Susak. Ugljan, Vir and Zlarin. So out analysis cover at least 15 from 47 permanently inhabited islands. Table 1 contains basic data on islands that are known, that are covered with the analysis.

Table 1. Basic data about islands in the sample, descriptive statistics

\begin{tabular}{|l|r|r|r|r|r|r|}
\hline \multicolumn{1}{|c|}{ Variable } & $\begin{array}{l}\text { Number of } \\
\text { islands }\end{array}$ & Mean & Median & Minimum & Maximum & $\begin{array}{c}\text { Std. } \\
\text { Dev. }\end{array}$ \\
\hline Island area, $\mathbf{~ k m}^{\mathbf{2}}$ & 15 & 105.1 & 51.1 & 3.8 & 405.7 & 140.8 \\
\hline Length of coast, km & 15 & 99.3 & 70.2 & 12.9 & 302.5 & 94.3 \\
\hline $\begin{array}{l}\text { Number of settlements on } \\
\text { the island }\end{array}$ & 15 & 11 & 5 & 1 & 68 & 18.0 \\
\hline $\begin{array}{l}\text { Average population density } \\
\text { (inhabitant/:km }\end{array}$ & 15 & 51.1 & 37.3 & 5.4 & 135.7 & 43.1 \\
\hline
\end{tabular}

Source: authors analysis based on Croatian bureau of statistics data

Table 2 shows the characteristics of the sample. As can be seen, the questionnaire was mostly answered by people living permanently on the island, and they make up 87 percent of the total number of respondents. The remaining 13 percent are people which live on the island for more than 3 months a year. Such a structure of respondents allows us to examine the respondents' perception of the influence of the government policy on everyday life on the island.

Table 2. Sample characteristics

\begin{tabular}{|l|l|c|}
\hline \multicolumn{2}{|c|}{ Variable } & $\%$ \\
\hline \multirow{2}{*}{ Gender } & Male & 41.7 \\
\cline { 2 - 3 } & Female & 58.3 \\
\hline \multirow{3}{*}{ Education } & Secondary school & 35.8 \\
\cline { 2 - 3 } & University of higher & 64.2 \\
\hline \multirow{3}{*}{$\begin{array}{l}\text { Living status on } \\
\text { the island }\end{array}$} & $18-34$ & 17.8 \\
\cline { 2 - 3 } & $35-59$ & 68.2 \\
\cline { 2 - 3 } & $60+$ & 14.0 \\
\cline { 2 - 3 } & Permanent inhabitant & 87.0 \\
\hline
\end{tabular}

Source: authors' analysis based on survey data 
The paper examines the islanders' opinions about the living conditions on the island. Figure 3 shows the perception of respondents about living conditions on Croatian islands.

Figure 3. Perception of living conditions on islands

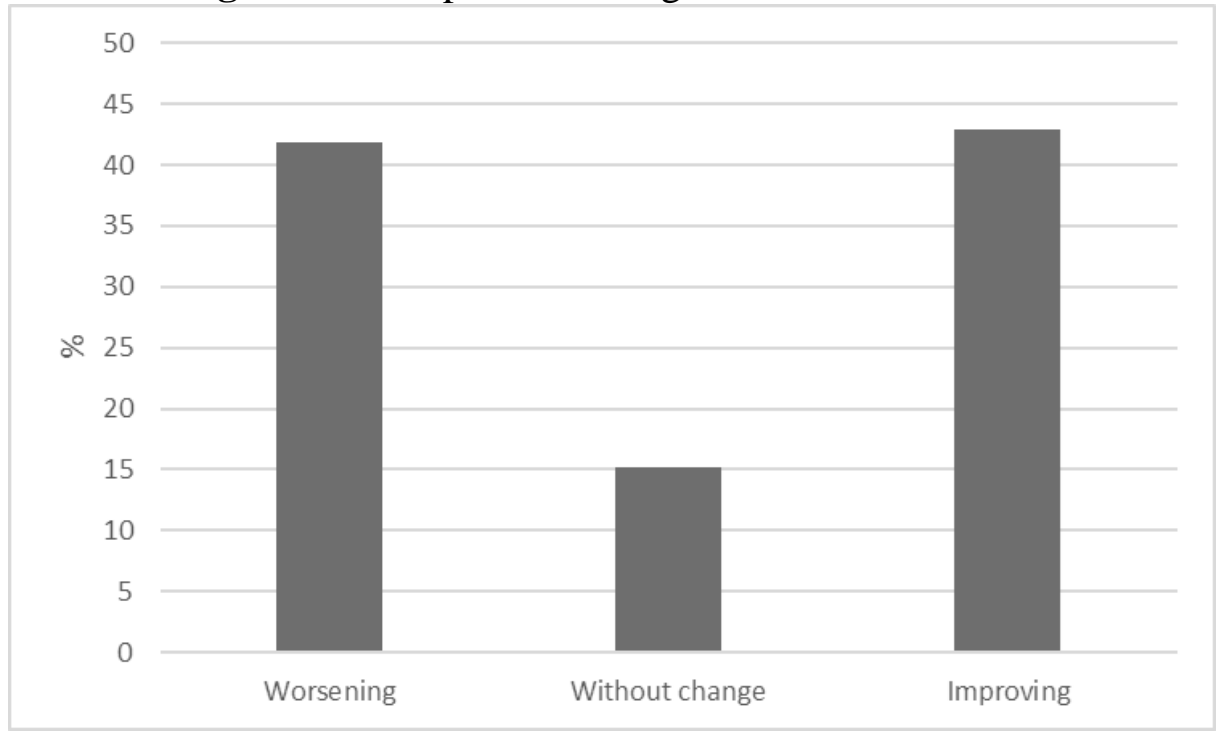

Source: authors' analysis based on survey data

Looking on average, around 42 percent of respondents think that living conditions on islands have improved, while 15 percent of them think that there is no change in the living conditions on islands.

Figure 4. Living conditions on islands has been improving

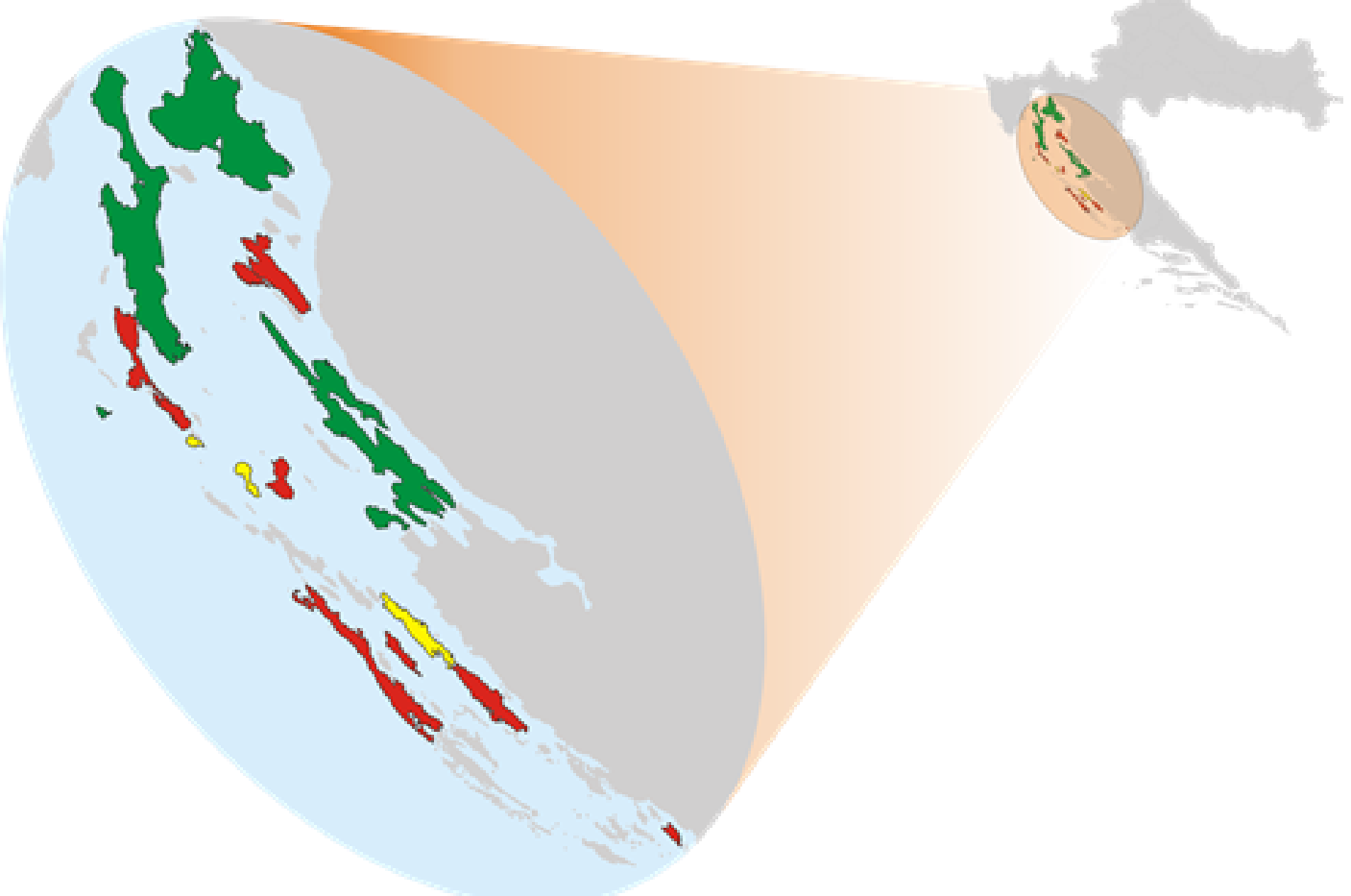

Note: red - islands where most of the respondents disagree with the statement, yellow islands where respondents neither disagree nor agree with the statement, green - islands where respondents mostly agree with the statement.

Source: authors' analysis based on survey data 
Figure 4 shows the differences in average attitudes of respondents about the living conditions on different islands. On island Pag, Cres, Krk, Vir and Susak respondents, looking on average, feel that living conditions have improved. The islands on which the respondents, looking on average, have an opinion that the living conditions on the islands have neither improved nor worsened are Ugljan, Ilovik and Silba. On islands, Rab, Pašman, Olib, Lošinj, Dugi otok, Iž and Zlarin most of the respondents have the opinion that the living conditions are worsening.

In the next step, we wanted to explore what people who live permanently or occasionally on the islands think about government policy focused on the islands. In particular, whether the state encourages the development of the island with its island policy. Figure 5 shows the results of the survey.

Figure 5. Impact of government policy on the development of islands

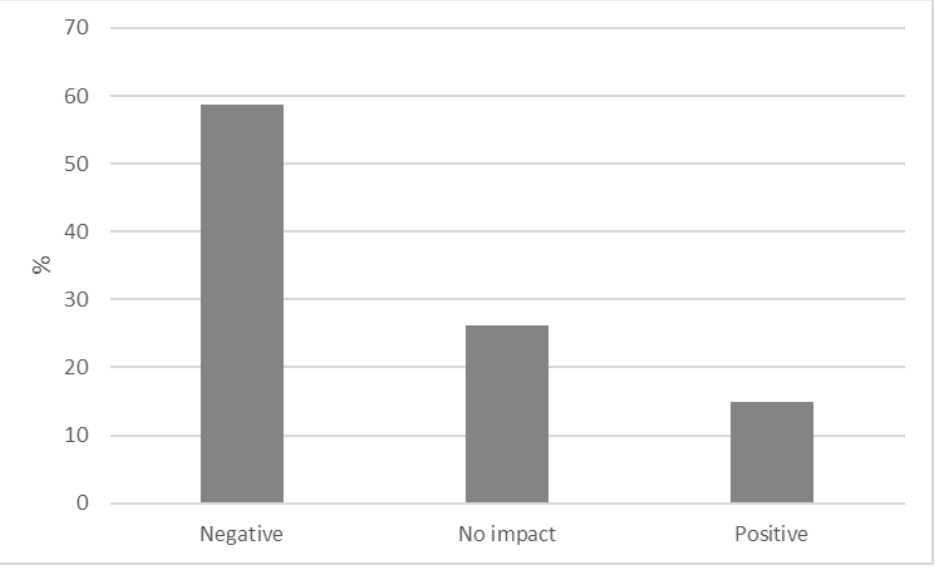

Source: authors' analysis based on survey data

As many as 85 percent of respondents have a negative opinion about the island's policy conducted by the state. Thus, 59 percent of respondents believe that the government does not encourage the development of the island. Besides, 26 percent of respondents believe that government island policy has no impact on island development. Only 15 percent of respondents believe that the government encourages the development of the island.

A chi-square test was conducted to determine differences in attitudes between respondents about living conditions on islands and government island policy. Results are presented in table 3.

Table 3. Chi-square test

\begin{tabular}{|c|c|c|c|}
\hline & Do not agree, \% & $\begin{array}{l}\text { Neither agree nor } \\
\text { disagree, \% }\end{array}$ & Agree, \% \\
\hline \multicolumn{4}{|c|}{ Living conditions on islands has been improving } \\
\hline \multicolumn{4}{|c|}{ Age (Pearson chi-square: $\left.14.598, \mathrm{df}=8, \mathrm{p}=0.067^{* *}\right)($ in $\%)$} \\
\hline 18-34 & 26.3 & 26.3 & 47.4 \\
\hline 35-59 & 38.9 & 15.3 & 45.8 \\
\hline $60+$ & 78.6 & 0.0 & 21.4 \\
\hline \multicolumn{4}{|c|}{ Island area (Pearson chi-square: $5.238, \mathrm{df}=8, \mathrm{p}=\mathbf{0 . 7 3 2}$ (in \%) } \\
\hline $1-15 \mathrm{~km}^{2}$ & 57.1 & 28.6 & 14.3 \\
\hline $15-50 \mathrm{~km}^{2}$ & 28.6 & 14.3 & 57.1 \\
\hline Larger than $50 \mathbf{k m}^{2}$ & 41.3 & 14.1 & 44.6 \\
\hline \multicolumn{4}{|c|}{ Number of inhabitants on the island (Pearson chi-square: $11.748, \mathrm{df}=12, \mathrm{p}=0.466$ ) } \\
\hline $85-300$ & 62.5 & 25.0 & 12.5 \\
\hline 301-3000 & 60.0 & 13.3 & 26.7 \\
\hline
\end{tabular}




\begin{tabular}{|c|c|c|c|}
\hline $\begin{array}{l}3001-7000 \\
\text { More than } 7001\end{array}$ & $\begin{array}{l}27.3 \\
42.9 \\
\end{array}$ & $\begin{array}{l}15.2 \\
12.2 \\
\end{array}$ & $\begin{array}{l}57.6 \\
44.9 \\
\end{array}$ \\
\hline \multicolumn{4}{|c|}{ County (Pearson chi-square: $8.103, \mathrm{df}=8, \mathrm{p}=\mathbf{0 . 4 2 3}$ ) } \\
\hline $\begin{array}{l}\text { Primorje-Gorski kotar } \\
\text { County } \\
\text { Zadar County } \\
\text { Šibenik-Knin County }\end{array}$ & $\begin{array}{l}37.7 \\
52.2 \\
100\end{array}$ & $\begin{array}{l}13.0 \\
13.0 \\
0.0\end{array}$ & $\begin{array}{l}49.3 \\
34.8 \\
0.0\end{array}$ \\
\hline \multicolumn{4}{|c|}{ 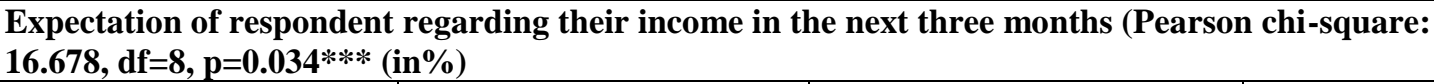 } \\
\hline $\begin{array}{l}\text { Increase } \\
\text { Stay the same } \\
\text { Decrease } \\
\end{array}$ & $\begin{array}{l}42.1 \\
27.3 \\
50.9 \\
\end{array}$ & $\begin{array}{l}5.3 \\
21.2 \\
14.5 \\
\end{array}$ & $\begin{array}{l}52.6 \\
51.5 \\
34.5 \\
\end{array}$ \\
\hline \multicolumn{4}{|c|}{ Government conduct policy which encourages the development of islands } \\
\hline \multicolumn{4}{|c|}{ Age $($ Pearson chi-square: $18.563, \mathrm{df}=8, \mathrm{p}=0.017 * * *)$} \\
\hline $\begin{array}{l}18-34 \\
35-59 \\
60+ \\
\end{array}$ & $\begin{array}{l}36.8 \\
64.8 \\
53.3 \\
\end{array}$ & $\begin{array}{l}52.6 \\
22.5 \\
13.3 \\
\end{array}$ & $\begin{array}{l}10.5 \\
12.7 \\
33.3 \\
\end{array}$ \\
\hline \multicolumn{4}{|c|}{ Island area (Pearson chi-square: $11.344, \mathrm{df}=8, \mathrm{p}=0.183 \%$ ) } \\
\hline $\begin{array}{l}1-15 \mathrm{~km}^{2} \\
15-50 \mathrm{~km}^{2} \\
\text { Larger than } 50 \mathrm{~km}^{2}\end{array}$ & $\begin{array}{l}42.9 \\
57.1 \\
59.8 \\
\end{array}$ & $\begin{array}{l}14.3 \\
28.6 \\
27.2 \\
\end{array}$ & $\begin{array}{l}42.9 \\
14.3 \\
13.0 \\
\end{array}$ \\
\hline \multicolumn{4}{|c|}{ Number of inhabitants on the island (Pearson chi-square: $20.572, \mathrm{df}=12, \mathrm{p}=0.057 * *)$} \\
\hline $\begin{array}{l}85-300 \\
301-3000 \\
3001-7000 \\
\text { More than } 7001 \\
\end{array}$ & $\begin{array}{l}50.0 \\
66.7 \\
60.6 \\
55.1 \\
\end{array}$ & $\begin{array}{l}12.5 \\
20.0 \\
36.4 \\
24.5\end{array}$ & $\begin{array}{l}37.5 \\
13.3 \\
3.0 \\
20.4 \\
\end{array}$ \\
\hline \multicolumn{4}{|c|}{ County (Pearson chi-square: $7.669, \mathrm{df}=8, \mathrm{p}=0.466$ ) } \\
\hline $\begin{array}{l}\text { Primorje-Gorski kotar } \\
\text { County } \\
\text { Zadar County } \\
\text { Šibenik-Knin County }\end{array}$ & $\begin{array}{l}58.0 \\
65.2 \\
25.0\end{array}$ & $\begin{array}{l}24.6 \\
26.1 \\
25.0\end{array}$ & $\begin{array}{l}17.4 \\
8.7 \\
50.0\end{array}$ \\
\hline \multicolumn{4}{|c|}{$\begin{array}{l}\text { Expectation of respondent regarding their income in the next three months (Pearson chi-square: } \\
16.609, \mathrm{df}=8, \mathrm{p}=0.034^{* * *)}\end{array}$} \\
\hline $\begin{array}{l}\text { Increase } \\
\text { Stay the same } \\
\text { Decrease }\end{array}$ & $\begin{array}{l}73.7 \\
41.2 \\
64.8 \\
\end{array}$ & $\begin{array}{l}21.1 \\
41.2 \\
18.5 \\
\end{array}$ & $\begin{array}{l}5.3 \\
17.6 \\
16.7 \\
\end{array}$ \\
\hline
\end{tabular}

Source: authors' analysis based on survey data

The results shown in the table indicate that the size of the island measured by the area of the island and the number of inhabitants on the island does not affect the existence of statistically significant differences in the attitudes of the respondents. However, the share of respondents who believe that island conditions are not improving is higher on small islands than on medium and large islands measured by the island area. Only 15 percent of respondents from islands which have an area smaller than $15 \mathrm{~km}^{2}$ is optimistic regarding living condition on islands. Also, the smallest number of those who feel that situation on islands is improving comes from smaller islands in terms of population, i.e. from islands with less than 3000 inhabitants. Belonging to an individual county does not affect the statistically significant difference in attitudes, although more respondents who believe that island conditions are worsening come from islands located in Šibenik-Knin County, and a quarter of them think that government does not encourage island development.

On average, there are statistically significant differences in the attitudes of different age groups on this issue. 79 percent of respondents older than 60 have an opinion that island conditions are not improving and only 26 percent of respondents aged 18 to 34 have the same attitude. 
The results further show that respondents of different age groups have different views on government island policy as well. Thus, 65 percent of respondents between the ages of 35 and 59 and 53 percent of respondents over the age of 60 believe that the government implements an island policy that does not encourage the development of all islands.

The results also indicate that there are statistically significant differences in the attitudes of residents depending on their expectations regarding their income in the next 3 months. Thus, 51 percent of respondents who expect that their income will decline in the future believe that living conditions on the islands are worsening. Interestingly, such an attitude is shared by 42 percent of respondents who expect an increase in income, while it is least represented among respondents who do not expect a change in income in the next 3 months.

\section{CONCLUSION}

Presented results indicate that island policy has not changed significantly in the recent 20 years. The main problems are limited employment opportunities, an increasingly elderly population, inadequate health care, and rare connections with the mainland. In the situation of the COVID19 pandemic $^{11}$, island development policy becomes even more challenging and complex. E.g. COVID-19 pandemic could compromise the entire national health system. Therefore, there are still many questions on the research agenda related to the quality of everyday island life, especially on the small islands. The results show that government policy particularly neglects the development of the small island, so the policy measures should target small islands more effectively. Small islands have not yet gained from the 1999 Islands Act and "they have not become equal parts of Croatia in terms of development policy" (Kordej-De Villa and Starc, 2020: 245). As tourism is an important sector of the Croatian economy and in the situation of COVID-19 pandemic it has experienced a great loss, research of adjustments of tourism capacities and infrastructure will attract special attention.

\section{REFERENCES}

Babić, D.; Lajić, I. i Podgorelec, S. (2004). Otočni izazovi: život na periferiji, odlazak ili revitalizacija otočnog mikrosocijalnog ambijenta. Sociologija i prostor: časopis za istraživanje prostornoga i sociokulturnog razvoja, 42 (3/4) (165/166), 255-276.

Izvješće o učincima provedbe Zakona o otocima, different years. Ministry of Regional Development and EU funds, https://razvoj.gov.hr.

Kordej-De Villa, Ž. and Starc, N. (2020). On the Rim of Croatia and Croatian Development Policies in Starc, N. (ed.) The Notion of Near Islands, The Croatian Archipelago. 215248. Lanham, Maryland: Rowman\&Littlefield.

Marinković, V. (2018): Croatian Islands - insight into the traffic - geographical features of accessibility, Geoadria, 23/2, 177-205

Marinković, V. (2018a): Spatial development processes of Croatian islands - the analysis of island settlements in terms of the quantity and quality of their central functions, Sociologija i proctor, 56, 210(1), 3-34.

Podgorelec, S.; Gregurović, M., Klempić Bogadi, S. (2015). Satisfaction with the quality of life on Croatian small islands: Zlarin, Kaprije and Žirje. Island Studies Journal, 10 (1), 91-110.

Sindico, F.; Sajeva, G.; Sharman, N.; Berlouis, P. i Ellsmoor, J. (2020). Islands and COVID19: A Global Survey,

11 For the responses to COVID-19 can be found in Sindico et al. (2020). 
https://www.strath.ac.uk/media/1newwebsite/departmentsubject/law/strathclydecentrefo renvironmentallawandgovernance/pdf/eilean/Islands_and_COVID_Booklet_v5_pages.p df.

Smart Island Declaration, http://www.smartislandsinitiative.eu/en/declaration.php.

Resolution on the special situation of islands, https://oeil.secure.europarl.europa.eu/oeil/popups/printficheglobal.pdf?id=661898\&l=e n.

Starc, N., ed., (2017). Analitička podloga za izradu novog Zakona o otocima, Studija, Zagreb: Ekonomski institut, Zagreb.

Starc, N. et al., ed. 1997. National Island Development Program. Zagreb: Ministry of Development and Construction of the Republic of Croatia. 